\title{
A Case with Abrupt Progression of Renal Scarring or Abrupt Deterioration of Renal Function Associated with Vesicoureteral Reflux
}

\author{
Moon Kyu Kim, M.D., Sung Eun Park, M.D. and Jun Ho Lee, M.D. \\ Departments of Pediatrics, CHA Bundang Medical Center, CHA University, Seongnam, Korea
}

\section{$=$ Abstract $=$}

Abrupt progression of renal scarring associated with vesicoureteral reflux (VUR) is rare in males over 2 years old of age. We report a 5 year old boy with sustained unilateral high grade VUR who experienced abrupt progression of renal scarring; he had a relative renal radionuclide uptake of $38 \%$ at 2 years of age that dropped to $8 \%$ after three years. Per his parent's wishes, he took prophylactic antibiotics for 25 months after his first febrile urinary tract infection (UTI) at 4 months old without surgical management. One episode of recurrent breakthrough infection occurred at the age of 2 years. This observation reminds us that a recommending surgical management for sustained high grade VUR associated with renal scarring might be needed. Close follow up of DMSA for renal scanning, and long term follow up of patients after the first febrile UTI are important. (J Korean Soc Pediatr Nephrol 2011;15:179-183)

Key Words : Dimercaptosuccinic acid renal scan, High grade vesicoureteral reflux, Renal scarring, Urinary tract infection

This is an open-access article distributed under the terms of the Creative Commons Attribution Non-Commercial License (http://creativecommons.org/licenses/bync/3.0/) which permits unrestricted non-commercial use, distribution, and reproduction in any medium, provided the original work is properly cited.

\section{Introduction}

Retrospective reviews of children with primary vesicoureteral reflux (VUR) have estimated that patients with high grade VUR are 4-6 times more likely to have scarring than

접수 : 2011년 7월 29일, 수정 : 2011년 8월 31일 승인 : 2011년 9월 1일

책임저자 : 이준호, 경기도 성남시 분당구 야탑동 351 차의과대학교 분당차병원 소아청소년과

Tel : 031) 780-5011, Fax : 031) 780-5011

E-mail : naesusana@yahoo.co.kr those with low grade VUR and 8-10 times more likely than patients without VUR [1]. The association of renal scarring with urinary tract infection (UTI) and VUR is termed reflux nephropathy [2]. Reflux nephropathy is usually acquired at a young age, and accompanies a higher risk of developing hypertension and progressive renal failure later in life, and thus requires lifelong follow up [3]. A retrospective report on a 15 year follow-up by imaging of patients with reflux nephropathy showed that there has been no case of a patient with abrupt 
deterioration of renal scarring [4].

We report the case of a child with sustained high grade VUR who experienced the abrupt progression of renal scarring without other risk factors for renal scarring.

\section{Case report}

A 4 month old boy was admitted to our hospital with the diagnosis of a first febrile UTI on December 2004. He had a day of high fever and no other symptoms upon admission. His blood pressure was $85 \mathrm{mmHg}$ systolic and 38 $\mathrm{mmHg}$ diastolic. Heart rate was 150 beats/min and body temperature was $39.9^{\circ} \mathrm{C}$. He weighed $7.8 \mathrm{~kg}$ (50-75th percentile) and was $66 \mathrm{~cm}$ tall (50-75th percentile). There were no remarkable findings on physical examination, family history, or the prenatal sonogram. He was uncircumcised. The fever subsided three days after administration of intravenous ceftriaxone. He was discharged 6 days after admission, and then he took oral antibiotics for 8 days. The laboratory findings at admission were as follows: Hgb 11.6 g/dL, WBC 13,200/ $\mathrm{mm}^{3}$, albumin $4.4 \mathrm{~g} / \mathrm{dL}$, BUN $10.9 \mathrm{mg} / \mathrm{dL}$, serum creatinine $0.4 \mathrm{mg} / \mathrm{dL}$, CRP $4.08 \mathrm{mg} / \mathrm{dL}$, urine dipstick test positive for occult blood, nitrite, leukocyte esterase, urine microscopy RBC 1030/high power field (HPF), WBC many/ HPF, and urine culture growth of E. coli $>10^{5}$ colony forming units/mL. Renal ultrasound (US) and 99m-dimercaptosuccinic acid (DMSA) renal scan were performed during admission. US showed increased echogenicity of the upper pole of the left kidney with normal kidney size (right kidney $6.3 \mathrm{~cm}$, left kidney $6.4 \mathrm{~cm}$ ). DMSA scan showed diffusely decreased renal uptake of $39 \%$ and two focal cortical defects with loss of renal contour on upper and lower poles of the left kidney (Fig. 1A). Voiding cystourethrogram (VCUG) revealed unilateral grade 5 VUR on the left side. After treatment of UTI, oral prophylactic antibiotic (trimethoprim-sulfamethoxazole) was administered continuously for 25 months. One year after the first febrile UTI, a second DMSA scan was performed and showed diffusely decreased renal uptake of $38 \%$ and no cortical defects (Fig. 1B). His parents did not follow the recommendation for surgical management for VUR. Twenty-four months after the patient's first febrile UTI, a third DMSA scan was performed and demonstrated diffusely decreased renal uptake of $32 \%$ and one cortical defect on the upper pole of the left kidney (Fig. 1C). Twenty-five months after the patient's first febrile UTI, a second UTI occurred with one day of fever that was controlled by oral antibiotics. Since that time, the patient was lost to follow up for three years from February 2007. On April 2010 he revisited our clinic for the purpose of performing follow up imaging studies. There were no significant findings on medical history including recurrent UTI, admission to a hospital, voiding disturbance, or constipation over the past three years. At the last visit his vital signs were stable. He weighed $19.5 \mathrm{~kg}$ (50th percentile) and was $114 \mathrm{~cm}$ tall (50-75th percentile). His urinalysis was normal. The last follow up US showed size discrepancy between his kidneys (right kidney $9.3 \mathrm{~cm}$, left kidney $6.6 \mathrm{~cm}$ ), and grade 1 hydronephrosis of the left side (defined by Society for Fetal Urology). The patient's last 

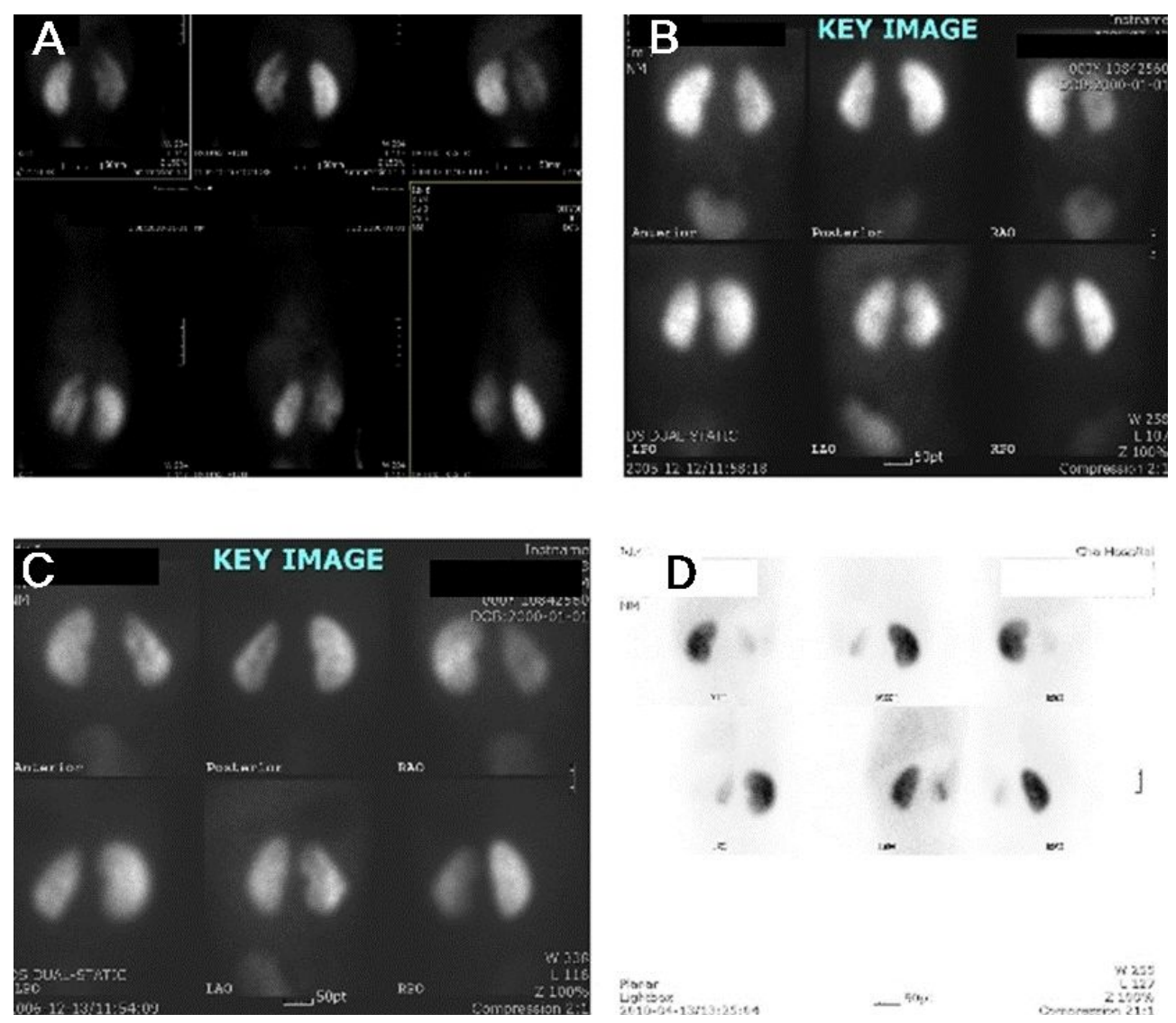

Fig. 1. Dimercaptosuccinic acid renal scan findings at 4 months (A), at 16 months (B), at 28 months (C), and at 5 years (D).

follow up DMSA scan showed near disappearance of his left kidney, with a relative renal uptake of $8 \%$ (Fig. 1D). His last follow up VCUG revealed unilateral grade 4 VUR on the left side. At that time, he was transferred to an outside hospital, where his parents wanted to go for surgical management.

\section{Discussion}

Many male infants are born with dysplastic kidneys and also have VUR [5]. Most dysplastic kidneys and VUR are detected in the process of imaging studies for febrile UTI. The DMSA scan is the gold standard for detection of renal scarring which was defined as decreased uptake with distortion of the contours or cortical thinning with loss of parenchymal volume $[6,7]$. Renal scarring was classified as primary (reflux associated) or acquired (without signs of scarring at the first investigation) [8]. Moreover, development of new renal scarring is often detected after acute pyelonephritis [9]. The grade of reflux and number of pyelonephritic attacks correlated with scarring, and number of pyelonephritic attacks with new scars and worsening of the lesions $[10,11]$. A prospective study reported that new scars occurred mostly 
in children under 5 years of age regardless of medical or surgical treatment and were observed more frequently in children with grade IV than grade III reflux [12]. Such renal scars might progress slowly to reflux nephropathy with recurrent pyelonephritis and development of proteinuria or hypertension [13]. However, a report suggested that one episode of acute pyelonephritis could lead to severe renal damage in a child with VUR although its exact pathogenesis was not known. In this case a component of congenital dysplasia was mild, even though a clear differentiation between congenital and acquired renal scarring was difficult. Moreover, the progression of renal damage in this case was so rapid and abrupt that unrecognized recurrent UTI or high grade VUR alone could not be considered as its cause. In these situations, it could be assumed that host susceptibility to renal scarring would be related to the rapid progression of renal scarring. In relation to scar formation in reflux nephropathy, there is some evidence for a role of angiotensin converting enzyme (ACE) gene polymorphism [14]. The DD genotype and D allele of ACE may be genetic susceptibility factors contributing to scar formation in VUR [14]. Another possible cause of rapid and diffuse renal scarring in the absence of urinary tract infection is a secondary obstruction of the urinary tract [15] . However, experiments have shown that extreme hydrodynamic conditions are required to produce progressive renal scarring, for example, in some infants with posterior urethral valves or in some children with a neurogenic bladder or dysfunctional voiding [15]. Moreover, sustained reflux with an abnormally high bladder pressure can flatten the area cribrosa of an initially non-refluxing papilla, converting its morphology to make it prone to intrarenal reflux [16]. The clinical importance of the mechanism of sterile reflux associated scarring remains controversial.

In summary, the possibility of abrupt progression of renal scarring in VUR patients makes clinicians alert for the presence or absence of renal scarring, a rational choice of surgical management for sustained high grade VUR associated with renal scarring, and the importance of following up DMSA renal scanning as well as the importance of long term follow up of patients for other predisposing factors of renal scarring after the first febrile UTI.

\section{한 글 요 약}

\section{고등급의 방광요관역류가 있는 환아에서 급격히 진행된 신반흔

\author{
김문규 · 박성은 - 이준호 \\ 차의과학대학교 분당차병원 소아청소년과
}

영아때 방광요관역류 환아로 진단된 남아중 2세 가 넘어 후천적으로 신반흔이 급격히 악화되는 경우 는 드물다. 본 증례는 생후 4 개월 때 첫 열성 요로감 염으로 입원하여, 왼쪽 5 등급 방광요관역류로 진단 되었고, 부모가 수술을 원치 않아 2년간 예방적 항생 제 요법만 시행받았다. 생후 29개월 때 열성 요로감 염이 한 차례 재발하였고, 이후 3 년간 추적관찰되지 않았다. 이 후, 5 세 때 본원을 방문하여 신장초음파, DMSA 신스캔, 배뇨성 방광요도조영술을 재시행받 았다. 추적 DMSA 신스캔에서 왼쪽 신상대섭취율이 생후 2세경 $38 \%$ 였으나, $8 \%$ 까지 떨어졌으며, 왼쪽 방광요관역류는 4 등급으로 남아있었다. 현재 방광요 관역류의 수술적 요법이 신기능의 예후와 관련이 없 
다고 알려져 있으나, 이런 증례를 볼 때, 아직은 신반 흔을 동반한 고등급의 방광요관역류 환자들에게 수 술적 요법을 권유하는 것이 임상의들에겐 타당하다 고 볼 수 있으며, 어떤 치료요법이 선택되어지든 상 관없이 첫 요로감염 이후 환자를 장기적인 추적관찰 하는 것이 중요하다고 사려된다.

\section{References}

1) Practice parameter: the diagnosis, treatment, and evaluation of the initial urinary tract infection in febrile infants and young children. American Academy of Pediatrics. Committee on Quality Improvement. Subcommittee on Urinary Tract Infection. Pediatrics 1999; 103:843-52.

2) Hodson CJ. The effects of disturbance of flow on the kidney. J Infect Dis 1969;120: 54-60.

3) Ransley PG, Risdon RA. The renal papillae, intrarenal reflux and chronic pyelonephritis. In: Hodson CJ, Kincaid-Smith P (eds). Reflux Nephropathy. New York : Masson Publishing, 1979:126-33.

4) Goonassekera CD, Gordon I, Dillon MJ. 15year follow-up of reflux nephropathy by imaging. Clin Nephrol 1998;50:224-31.

5) Swerkersson S, Jodal U, Sixt R, Stokland E, Hansson S. Relationship among vesicoureteral reflux, urinary tract infection and renal damage in children. J Urol 2007;178:64751.

6) Saadeh SA, Mattoo TK. Managing urinary tract infections. Pediatr Nephrol DOI 10. 1007/s00467-011-1801-5, 2011

7) Montini G, Zucchetta P, Tomasi L, Talenti E, Rigamonti W, Picco G, et al. Value of imaging studies after a first febrile urinary tract infection in young children: data from Italian renal infection study 1 . Pediatrics 2009;123:e239-46.

8) Wennerström M, Hansson S, Jodal U, Stokland E. Primary and acquired renal scarring in boys and girls with urinary tract infection. J Pediatr 2000;136:30-4.

9) Jakobsson B, Berg U, Swensson L. Renal scarring after acute pyelonephritis. Arch Dis Child 1994;70:111-5.

10) Shaikh N, Ewing AL, Bhatnagar S, Hoberman A. Risk of renal scarring in children with a first urinary tract infection: a systematic review. Pediatrics 2010;126:1084-91.

11) Martinell J, Hansson S, Claesson I, Jacobsson B, Lidin-Janson G, Jodal U. Detection of urographic scars in girls with pyelonephritis followed for 13-38 years. Pediatr Nephrol 2000;14:1006-10.

12) Olbing H, Smellie JM, Jodal U, Lax H. New renal scars in children with severe VUR: a 10-year study of randomized treatment. Pediatr Nephrol 2003;1128-31.

13) Cendron M. Reflux nephropathy. J Pediatr Urol 2008;4:414-21.

14) Haszon I, Friedman AL, Papp F, Bereczki C, Baji S, Bodroqi $\mathrm{T}$, et al. ACE gene polymorphism and renal scarring in primary vesicoureteric reflux. Pediatr Nephrol 2002; 17:1027-31.

15) Ransley PG, Risdon RA, Godley ML. High pressure sterile reflux and renal scarring: an experimental study in the pig and minipig. In: Hodson CJ, Heptinstall RH, Winberg J (eds) Contributions to nephrology, vol 39, Karger, Basel, 1984:164-8.

16) Ransley PG, Risdon RA. Reflux and renal scarring. Br J Radiol [Suppl] 1978;14:1-35. 